\title{
Children in internet space - the European Union policies on children's safety online
}

\author{
Justyna Wojniak ${ }^{1 a}$, Marta Majorek ${ }^{2}$ \\ ${ }^{1}$ Pedagogical University of Cracow, Podchorążych 2, Cracow 30-084, Poland \\ ${ }^{2}$ Andrzej Frycz Modrzewski Cracow University, Herlinga-Grudzińskiego 1, Cracow 30-705, Poland
}

\begin{abstract}
Nowadays more and more attention is paid to increasing activity of the young people, including children, in the Internet space. Making children aware of the dangers on the network and ways to protect them becomes crucial. This process involves not only parents and teachers. Issues related to security in the network are the focus of attention of the European Commission, as an executive body of the European Union, responsible for proposing legislation and implementing decisions. The paper presents key assumptions of the European Union policy and initiatives aimed at protecting the youth against the consequences of irresponsible use of information and communication technology.
\end{abstract}

Keywords: Information and communication technology; children safety online; European Union.

\section{Introduction}

Due to the recently growing access to the Internet, new technologies and services in Europe it is clear that today we live in a digital age. The younger generations are becoming more active in the online environment and the use of the Internet does not make them difficulty. However, one should not forget about dangers to which children and adolescents are exposed while using these tools. Hence, the strengthening of cooperation at the European and international level becomes necessary, not only to combat cybercrime, but also crimes such as the sexual exploitation of children and the distribution of online materials with such content (http://europa.eu/rapid/press-release_IP-12-445_pl.htm).

This opinion is fully justified if we take into account European statistics on the activity of children and adolescents in Internet space. The authors of the report EU Kids Online of October 2012 analyzed the current situation in 33 countries, including 27 EU Member States and candidate countries, (Croatia and Turkey), as well as in the European Economic Area and in Russia, [9]. According to the data, which provides the EU Kids Online report,

\footnotetext{
${ }^{\text {a } C o r r e s p o n d i n g ~ a u t h o r: ~ j w o j n i a k @ u p . k r a k o w . p l ~}$
} 
the use of the Internet is somehow inscribed in the everyday lives of young people, since $60 \%$ of $9-16$-year-olds use the web every day or almost every day. The most common place to use it is their house (87\%), followed by school $(63 \%)$. The ways of access are diversified: children and young people use the Internet from a computer (49\%), mobile phones and other mobile devices (33\%). It should be added that Internet in 2005 was used by $70 \%$ of $6-17$-year-olds, and in 2008 it was already $75 \%$.

Referring to the purpose of using the Internet, one can point to a number of key areas. The most popular is the use of the network for preparation for classes $(85 \%)$, followed by games $(83 \%)$, watching video materials $(76 \%)$, instant messaging $(62 \%)$. To a lesser extent, the Internet is used to upload images (39\%) and news (31\%), or used as a tool to use file sharing services used for (16\%) or blogging (11\%). Moreover, 59\% of young people aged 9-16 years have a profile on a social network site, this group is the largest among the 15-16year-olds and it is $82 \%$, however, already $26 \%$ of $9-10$-year-old also have a profile on these sites, [9].

Taking into account the results for each country, the authors of the report have identified four main groups [9]. The first is characterized by a tendency towards a smaller range of Internet usage and lower risk (lower usage, lower risk). This group contains the following countries: Austria, Belgium, France, Germany, Greece, Hungary and Italy. Children in these countries have the lowest usage of the Internet and are thus below the average level of risk. However, with the increase in the scope of the use of this medium the risk also may increase. In the second group we are dealing with a smaller scope of usage of the Internet and a certain degree of risk (lower use, some risk ). Spain, Ireland, Portugal and Turkey have been included to this group. Although the level of Internet usage by children is the lowest here, but there are certain risks. The third group is described as high level of usage and a certain degree of risk (higher usage, some risk). This tendency exists in Cyprus, Finland, the Netherlands, Poland, Slovenia and the UK. The limited degree of risk is associated with campaigns to increase awareness of the risks and promote parental control strategies which are being implemented in these countries. The last group is characterized by both a high level of Internet usage and a high level of risk (higher usage, higher risk). It consists of such countries as: Bulgaria, the Czech Republic, Estonia, Lithuania, Romania and the Nordic countries: Denmark, Norway and Sweden. What is noteworthy, this division does not result from the wealth of the country, as this group includes both wealthy Scandinavian countries and countries of Central and Eastern Europe. The authors describe this group using the term "new usage, new risk" which suggests new ranges of Internet usage, with the emergence of new threats.

In the light of the report, as many as $41 \%$ of young people aged $9-16$ years have experienced a variety of behaviors that they found threatening or disturbing, and among 1516 -year-olds the figure was $63 \%$. More concerning, however, is that in the group of children aged 9-10 it was 14\%. Investigated children considered pornographic, promoting hatred and aggressive attitude, presenting cases of anorexia, drug addiction and suicide as threatening or disturbing behavior. Among 11-16-year-olds 64\% know how to block unwanted contacts, the same group also declares the ability to search the network for security tips from unwanted behaviors or contacts. More than half can change privacy settings $(56 \%)$ or are able to block unwanted content (51\%), [9].

However, making children aware of the dangers on the network and ways to protect them becomes crucial. The central part in this process falls to parents and teachers. Issues related to security in the network are the focus of attention of the European Commission, which emphasized six key elements (Education, Audiovisual and Culture Executive Agency 2010). Among them should be noted safe online behavior, which is understood as paying attention to the dangers of improper or unlawful interest in children. This issue connects directly to the protection of privacy and non-disclosure of personal information, 
such as address, phone number or name of the school, as this data could help identify the child by the unwanted person.

Cyberbullying is another phenomenon, which one should pay special attention to. It is necessary to instruct students about the manifestations of this phenomenon, especially the transmission of offensive or embarrassing photos or messages by e-mail, placing them in blogs, profiles or websites, spreading rumors or stealing one's identity. In any case, teachers should emphasize the need for reporting such activities to parents or educators. Equally important is making students aware of the principles of obtaining and copying the content, thus the matter of copyright in relation to materials available on the network and to the limitations that are associated with their distribution and reproduction.

In the context of children safety one should not overlook the problem of making direct contact with the people they met in the network. The most important thing is alerting children to the possibility of manipulation and the potential danger that may occur while meeting such a person and focusing on necessary precautions.

In the context of network security issue relatively little attention is given to the safe use of mobile phones. This issue, however less exposed, seems important as most phones today have internet access, so there is also a need for similar precautions in disclosing personal data, as well as to warn young people in order to avoid sharing their phones. Other areas of network security issues refer to online gaming addiction, shopping on the web and spreading viruses.

It should be emphasized that at the elementary level of education, the issue of security in the network as part of the curriculum is mostly informal. For example, in Poland it is carried out by class teachers or within an integrated curriculum, often in the form of a project or group work. At the secondary level this topic is included in the field of information and communication technology, computer science. It can be also a part of general subjects, for instance in Portugal it is a part of civic education or in the UK it is incorporated in health and wellbeing education (Education, Audiovisual and Culture Executive Agency 2010) .

Issues concerning network security are addressed by both teachers in the area of information and communication technologies, as well as by teachers of other subjects, depending on the specific solutions adopted in the particular country (Education, Audiovisual and Culture Executive Agency 2010). The first model exists in Bulgaria, Cyprus, Latvia and Poland. In other countries, where the issue of network security is a part of the curriculum or belongs to integrated education, the appropriate teachers are responsible for the implementation of this content during their classes. In some cases, school authorities can assign a teacher responsible for teaching a content related subject to network security, depending on the design of the curriculum and the time available.

In countries where the issues discussed are incorporated into the curriculum, teachers participate in courses in which subjects are related to child protection in the network, and this problem is discussed at both the pedagogical and technical or organizational level. In most cases, however, such courses are not compulsory and they are organized by teacher training institutions or a consortia that promotes informed and safe usage of the network. Courses are promoted by the Ministry of Education through the national program for computer science teachers (Greece), and may also include training of the school heads who transfer knowledge to the teaching teams or individual teachers (France). In addition, education authorities provide teachers with material for self-study, which contain both information, tasks and exercises for students, as well as interactive online courses (Spain, Luxembourg, and the United Kingdom).

Almost all European Union Member Countries use various forms of public-private partnerships in their efforts to promote children safety online. This involves private sector participation at conferences and workshops on the issue discussed. Private sector 
involvement in campaigns to raise awareness of the risks in the network and inform children, parents and teachers. An important part of this involvement is also participation in long-term projects related to building technology infrastructure and the implementation of specific projects in schools.

In addition, in some countries private companies support public authorities, for example in the purchase of hardware or specialized software securing Internet connections or monitoring cases of unwanted access to school computers or networks from the outside. For example, in Poland the software to block access to sites containing undesirable or dangerous content was offered to schools free of charge via the Ministry of Education. This project was co-financed by the European Social Fund. Twenty thousand schools and twelve thousand libraries house such software. In addition, the Ministry of Education signed an agreement with one of the leading software companies for the implementation of the strategy of information society development Poland by 2013, with particular emphasis on schools and educational institutions. The Government Plenipotentiary for Equal Treatment has also decided about creating in 2008 a Team for Counteracting Discrimination of the Young in Electronic Mass Media. This group is composed of representatives of 70 public institutions and non-governmental organizations and the representative of the Ministry of Education. The Team has a separate sub-team which is responsible for online safety issues and works on legislation proposals, terms of cooperation, projects of educational campaigns and monitoring of the situation related to children/youth and mass media (http://rownetraktowanie.gov.pl/kalendarz-wydarzen/spotkanie-zespolu-ds-

przeciwdzialania-dyskryminacji-maloletnich-w-srodkach-0).

Undoubtedly the most important initiative implemented in order to protect children and young people in Internet space at the level of the European Union is the Safer Internet Program: Empowering and Protecting Children Online for the years 2009-2012. The program was initiated already in 1999, and implemented at national and European levels. The key points included increasing young people awareness of the threats in the network, removing illegal content, web content filtering, engaging civil society on the issue of children protection in the face of technology and the creation of an information base on the use of new technologies by children and young people, [4]. Under the program with a budget of $€ 55$ million a variety of projects aimed at creating a safe Internet space for young people has been established, as well as a promotion of self-regulation in the new technologies industry, cooperation with non-governmental organizations and the organization of the Safer Internet Forum and support of Safer Internet Day. Safer Internet Forum is organized since 2004 as an annual conference of the representatives of the computer industry, legislative and executive authorities of individual countries and organizations representing the rights of children, including those outside the European Union. In 2012, the Forum was held under the motto: "Creating together a Better Internet for Children and Young People". Safer Internet Day is celebrated on February, 7th in more than 70 countries. In 2012 the theme of the feast was: "Discover the digital world together...safely!"”.

Under the Program Safer Internet Centres operate in 30 countries. Their task is to promote the safe and responsible use of new technologies. This activity is carried out by raising among young people, their parents, carers and teachers through educational materials awareness of the potential risks posed by the use of new technologies. The Centres are involved in the organization of campaigns and information sessions, they also offer access to telephone lines, where experts provide young people, carers and teachers with tips on safe online behavior. The Safer Internet Centres can also report cases of sites with illegal content, especially materials on child abuse. This information, when appropriately verified shall be submitted to the authorities and Internet service providers, which shall then decide to take the necessary steps to prevent such risks,[6]. 
The Safer Internet Program also funds the activities of Interpol, as well as activities to raise awareness of the risks and consequences arising from the use information and communication technology by children and young people. In 2009-2012 the financing of Interpol activities came to 500000 EURO. Among these activities are: EU Kids Online II (Enhancing knowledge regarding to European children's use, risk and safety online), POG (Understanding the Process of online grooming: the Behaviours of men who target young people online), ROBERT Risktaking Online Behaviour - Empowerment through Research and Training and the EU-NET ADB: Research on the intensity and prevalence of the Internet addictive behavior risk among minors in Europe.

In May 2012 the European Commission presented an initiative entitled Digital Agenda: A New Strategy for a safer internet and better internet content for children and teenagers. It includes a plan to provide children with the skills and digital tools necessary for safe usage and taking full advantage of the digital world (http://europa.eu/rapid/press-release_IP-12445 pl.htm ). The goal of this document is to develop a partnership between the Commission, Member States, mobile operators, telephone manufacturers and suppliers of social networking services.

In this context, cooperation in the framework of the Coalition of top tech and media companies to make Internet better place for our kids is worth mentioning. In December 2011, 28 industry's leading high-tech and media companies formed under the auspices of the European Commission a coalition to ensure a higher level of safety for children on the Internet. The aim of this initiative is to facilitate reporting harmful content, customize the settings to protect the user's age and increase the range of parental control. The activities of the Coalition are focused on four main objectives, among which are mentioned stimulation of the building of creative and educational online content for children and the creation of platforms providing access to age-appropriate content. Another goal involves the intensification of information and instruction in all schools in the EU on safety rules on the Internet, enabling children to develop digital and media literacy as well as responsibility for themselves in the online environment. The Coalition also refers to creating a safe environment for children, in which parents and children will receive the tools necessary to ensure their protection in the online environment (easy-to-use mechanisms to report harmful content and behavior, transparent, default privacy settings suitable to user's age and user friendly parental control tools). The Coalition stresses also the necessity of fighting against online materials related to the sexual exploitation of children.

Initiatives outlined in the Coalition's strategy are based on current EU activities. For instance, designed for children, parents and teachers, easy-to-use mechanisms to report harmful content and behavior will complement the 116 emergency telephone number to report cases of missing children (http://europa.eu/rapid/press-release_IP-07188 en.htm?locale=en ). Part of these solutions is also a network of national platforms to report computer crimes to the European Cybercrime Centre (http://europa.eu/rapid/pressrelease_IP-12-317_en.htm?locale=en ).

The European Commission as one of the main links of the European Union institutional system obviously is interested not only in the development of these trends and their monitoring, but also in the introduction of specific regulations in this sphere which on the one hand encourage the fullest possible use of technological tools in schools, while creating mechanisms to protect children and youth from abuse and the dangers to which young people may be exposed.

\section{References}

1. Education, Audiovisual and Culture Executive Agency, Education on online safety in schools in Europe, (2010). 
2. European Commission, Agenda cyfrowa: Nowa strategia na rzecz bezpieczniejszego internetu i lepszych treści internetowych dla dzieci i nastolatków, Retreieved from http://europa.eu/rapid/press-release_IP-12-445_pl.htm, (2012).

3. European Commission, An EU Cybercrime Center to fight online criminals and protect e-consumers, Retreieved from http://europa.eu/rapid/press-release_IP-12317_en.htm?locale=en, (2012).

4. European Commission, Creating a Better Internet for Kids, Retreieved from http://ec.europa.eu/digital-agenda/en/creating-better-internet-kids, (2011).

5. European Commission, Digital Agenda: A New Strategy for a safer internet and better internet content for children and teenagers, http://europa.eu/rapid/press-release_IP-12445_pl.htm, (2012).

6. European Commission, Safer Internet Centres, Retreieved from https://ec.europa.eu/digital-agenda/en/safer-internet-centres, (2010).

7. European Commission, Safer Internet Day, Retreieved from http://www.saferinternet.org/web/guest/safer-internet-day, (2012).

8. European Commission, 116000 the single EU hotline number for missing children, Retreieved from http://europa.eu/rapid/press-release_IP-07-188_en.htm?locale=en, (2007).

9. Livingstone S., Haddon L., EU Kids Online: Final report, Retreieved from http://www.lse.ac.uk/medi a@lse/research/EUKids Online/EU\%20Kids\% 20I\%20(2006-9)/EU\%20Kids\%20Online\%20I\%20Reports/EUKidsOnlineFinalReport. pdf, (2009).

10. Pełnomocnik Rządu ds. Równego Traktowania, Counteracting Discrimination of the Young in Electronic Mass Media, Retreieved from http://rownetraktowanie.gov.pl/kalendarz-wydarzen/spotkanie-zespolu-dsprzeciwdzialania-dyskryminacji-maloletnich-w-srodkach-0, (2008). 